\title{
The influence of visionary leadership style and work motivation on the performance of paramount elementary school teachers in palembang
}

\author{
Rinaldo Alimin ${ }^{1}$, Happy Fitria ${ }^{2}$, Alfroki Martha ${ }^{3}$ \\ ${ }^{1}$ Paramount School Palembang \\ ${ }^{2}$ Universitas PGRI Palembang
}

\section{Article Info}

\section{Article history:}

Received Jul $11^{\text {th }}, 2021$

Revised Aug 19 ${ }^{\text {th }}, 2021$

Accepted Aug 30 ${ }^{\text {th }}, 2021$

\section{Keyword:}

Visionary leadership style work motivation teacher performance

\begin{abstract}
The principal as the pinnacle of leadership with a visionary leadership model must be able to improve the performance of Paramount Palembang Elementary School teachers. This visionary leadership can have a significant effect on improving teacher performance because the principal can provide a clear vision and can implement the vision he has made for the teacher's future, thereby providing motivation for improving teacher performance. The principal must be able to increase the strategic and technical role in improving the quality of learning and teaching, he is not only a learning leader but more than that the overall leader which includes leadership functions in a school institution such as planning, career coaching, coordination and evaluation. His leadership pattern is very influential and even determines the progress of education.The hypothesis in this study is that there is an influence of Visionary leadership style on the performance of Paramount Elementary School Palembang teachers. There is an influence of working motivation together on the performance of Paramount Primary School Palembang teachers. There is an influence of Visionary leadership style and work motivation together on the performance of Paramount Elementary School Palembang teachers. Data collection was carried out by observation, interviews and questionnaires. The analysis carried out is the correlation analysis of t-test and $\mathrm{F}$ test. The results of data analysis from the questionnaire show that there is an influence of Visionary leadership style on the performance of Paramount Elementary School Palembang teachers. There is an influence of work motivation on the performance of Paramount elementary school teachers in Palembang. There is an influence of Visionary leadership style and work motivation together on the performance of Paramount Elementary School Palembang teachers. (significant level 5\%).
\end{abstract}

(C) 2021 The Authors. Published by IICET

This is an open access article under the CC BY-NC-SA license (https://creativecommons.org/licenses/by-nc-sa/4.0

\section{Corresponding Author:}

Rinaldo Alimin

Paramount School Palembang

Email: rinaldoalimin@ymail.com

\section{Introduction}

The principal as the pinnacle of leadership with a visionary leadership model must be able to improve the performance of Paramount Palembang Elementary School teachers. This visionary leadership can have a significant effect on improving teacher performance because the principal can provide a clear vision and can 
implement the vision he has made for the teacher's future, thereby providing motivation for improving teacher performance. The principal must be able to increase the strategic and technical role in improving the quality of learning and teaching, he is not only a learning leader but more than that the overall leader includes leadership functions in a school institution such as planning, career development, coordination and evaluation. His leadership pattern is very influential and even determines the progress of education.

Visionary leadership, in this case the Principal of Paramount Palembang Elementary School, must be able to carry out his responsibility to lead the school successfully. Visionary leadership must know exactly what vision and mission it wants to achieve and how to realize that vision and mission in a given mandate. The visionary principal must understand how important it is to invite all related parties in his school to work together to realize the vision that has been formulated together. The implication of a visionary nature is that the principal must have a number of competencies and integrity to carry out the mission in order to realize that vision, and furthermore, the principal must also have a number of certain characters that demonstrate his integrity.

Based on the results of observations on March 25, 2020 at the Paramount Palembang Elementary School, researchers saw several problems, namely: The Principal of the Paramount Palembang Elementary School now has an average experience in leading a school and is considered capable of bringing about a change in the Paramount Palembang Elementary School in the future. . The school principal's workload, which has been felt to be too heavy, because of the many tasks that must be completed now with good managerial management from the Principal of the Paramount Palembang Palembang Elementary School, it can place people with the right abilities to help complete their duties as head.

The Principal of Paramount Palembang Elementary School certainly has good knowledge of leadership, skills and personality. The obstacles faced by the Principal of Paramount Palembang Elementary School which had been considered to be problems could be resolved properly. Seeing the leadership ability in leading the Paramount Palembang Elementary School is very positive so that there are teacher expectations about the leadership of the Palembang Paramount Primary School principal to be able to compete with other schools. Based on this, the authors are interested in conducting research with the title: "The Influence of Visionary Leadership Style and Work Motivation on Teacher Performance at Paramount Elementary Schools Palembang".

\section{Method}

The method of observation is systematic observation and recording of the symptoms that appear on the object of research. Observation is a data collection method that uses observation of the object of research that can be carried out directly or indirectly [1]. So in this study the authors used direct observation of the research location, especially the condition of the teachers of SD Paramount Palembang. The questionnaire is a data collection technique by sending a list of questions to respondents to fill in [2]. The questionnaire is a way of collecting data by sending a questionnaire containing a number of questions addressed to the person who is the object of research so that the answer is not immediately obtained [3]. The documentary method is a data collection tool called a document recording form, and the data source is in the form of notes or available documents. As well as student attendance in class activities, the document can be seen in the student attendance list [4]

Hypothesis testing is done statistically by testing it partially and simultaneously

1. Partial Test ( $t$ test)

a. First hypothesis

1. Ho: $\beta 1=0$ There is no influence of Visionary Leadership Style on teacher performance

$\mathrm{H} 1: \beta 1 \neq 0$ There is an influence of Visionary Leadership Style on teacher performance

2. Level of Significance $(\alpha)=0.05$

3. Test criteria:

Ho: accepted if $\mathrm{t}-\mathrm{sig} \geq 0.05$

H1: accepted if $\mathrm{t}-\mathrm{sig}<0.05$

4. Conclusions accept or reject $\mathrm{H} 0$

b. Second Hypothesis

1. Ho: $\beta 2=0$ There is no influence of work motivation on teacher performance

$\mathrm{H} 1: \beta 2 \neq 0$ There is an effect of work motivation on teacher performance

2. Level of Significance $(\alpha)=0.05$

3. Test criteria: 
Ho: accepted if $\mathrm{t}-\mathrm{sig} \geq 0.05$

$\mathrm{H} 1$ : accepted if $\mathrm{t}-\mathrm{sig}<0.05$

4. Conclusions accept or reject $\mathrm{HO}$

\section{Simultaneous Test (Test F)}

Third Hypothesis

1. Ho: $\beta 1=\beta 2=0$ There is no influence of Visionary Leadership Style and Work Motivation simultaneously on teacher performance

H1: $\beta 1 \neq \beta 2 \neq 0$ There is an influence of Visionary Leadership Style and Work Motivation simultaneously on teacher performance

2. Level of Significance $(\alpha)=0.05$

3. Test criteria:

Ho: accepted if $\mathrm{F}$ - sig $\geq 0.05$

H1: accepted if $\mathrm{F}$ - sig $<0.05$

\section{Results and Discussions}

Based on the results of research and discussion that has been carried out both through descriptive statistical analysis and inferential statistical analysis, as well as the findings in this study are as follows:1) There is an influence of the Visionary leadership style on the performance of Paramount Elementary School Palembang teachers at $59.9 \%$ with a $t$ value of 8.468 and a sig value of 0.000 . 2)There is an effect of Work Motivation on the performance of Paramount Elementary School Palembang teachers by $67.9 \%$ with a t value of 10.067 and a sig value of 0.000. 3)There is an influence of Visionary leadership style and Work Motivation together on the performance of Paramount Elementary School Palembang teachers at $68.2 \%$ with an F value of 50.349 . When viewed together Visionary leadership style and work motivation on teacher performance, the more influential variable is work motivation which has a greater influence on teacher performance with a beta value of 0.699 and sig 0.001 .

\section{Conclusions}

There is an influence of Visionary leadership style on the performance of Paramount Elementary School Palembang teachers. There is an influence of Work Motivation on the performance of Paramount Elementary School Palembang teachers. There is an influence of Visionary leadership style and work motivation together on the performance of Paramount Elementary School Palembang teachers.

\section{References}

Tanzeh. Ahmad. 2009. Practical Research Methodology. Jakarta: Earth Literacy.

Sukandarrumidi. 2012. Research Methodology: A Practical Guide for Researchers. Beginner. Gajah Mada University Press: Yogyakarta.

Boediono and Koster, Wayan. 2004. Statistics and Probability. Volume 3. Bandung: PT. Rosdakarya youth. Faisal, Sanapiah. 2007, Social Research Formats, Jakarta: Raja Grafindo Persada. 
